\title{
ANTIOXIDANT ACTIVITY FROM TEN SPECIES OF MYRTACEAE
}

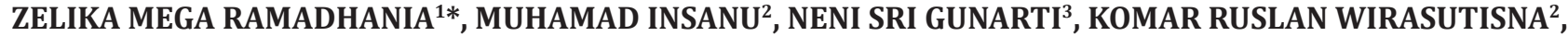 SUKRASNO SUKRASNO ${ }^{2}$, RIKA HARTATI ${ }^{2}$}

\author{
${ }^{1}$ Department of Pharmaceutical of Biology, Faculty of Pharmacy, Universitas Padjadjaran, West Java, Indonesia. ${ }^{2}$ Department of \\ Pharmaceutical of Biology, School of Pharmacy, Bandung Institute of Technology, West Java, Indonesia. ${ }^{3}$ Department of Pharmaceutical \\ Biology, Faculty of Pharmacy, Buana Perjuangan University, West Java, Indonesia. Email: zelika.mega@unpad@ac.id
}

Received: 24 September 2016, Revised and Accepted: 30 January 2017

\section{ABSTRACT}

Objective: Antioxidants are compounds that can inhibit free radical reactivity. They become very interesting to be observed because they can prevent some diseases such as goat arthritis, cancer, cardiovascular disease, Alzheimer's disease, and macular degeneration. Since Indonesia is rich for its biodiversity, there are a lot of plants that have potential to be developed as new alternative antioxidants. The aim of this research was to evaluate antioxidant activity from 10 species of Myrtaceae (Syzygium cumini, Syzygium samarangense, Syzygium aqueum, Syzygium aromaticum, Syzygium polyanthum, Syzygium jambos, Syzygium malaccense, Psidium guajava, Eucalyptus deglupta, and Melaleuca leucadendra).

Methods: Continuous extraction with Soxhlet apparatus was selected as extraction method. Three solvents (n-hexane, ethyl acetate, and methanol) with different polarity were used in this process. 2,2-diphenyl-1-picrylhydrazyl radical scavenging activity was used to evaluate antioxidant activity with ascorbic acid as a standard drug.

Results: Based on the experiments, methanol extracts showed higher activity than other extracts with their inhibitory concentration $50 \%\left(\mathrm{IC}_{50}\right)$ was below than $25 \mu \mathrm{g} / \mathrm{ml}$. The lowest $\mathrm{IC}_{50}$ was exhibited by methanol extract of $S$. jambos, which was $7.8 \mu \mathrm{g} / \mathrm{ml}$.

Conclusion: It can be concluded that $S$. jambos is potential to be developed as a new alternative antioxidant.

Keywords: Antioxidants, Eucalyptus, Syzygium, Melaleuca, Psidium, 2,2-diphenyl-1-picrylhydrazyl.

(c) 2017 The Authors. Published by Innovare Academic Sciences Pvt Ltd. This is an open access article under the CC BY license (http://creativecommons. org/licenses/by/4. 0/) DOI: http://dx.doi.org/10.22159/ajpcr.2017.v10s2.19470

\section{INTRODUCTION}

Antioxidants are substances that may protect cells from the damage caused by unstable molecules (free radicals) [1]. Cell damage caused by free radicals appears to be a major contributor to aging and to degenerative diseases of cancer, cardiovascular diseases, cataracts, immune system decline, and brain dysfunction [2]. In general, free radicals have been implicated in the pathogenesis of at least 50 diseases [3]. Several studies have shown that plant-derived antioxidant nutraceuticals scavenge free radicals and modulate oxidative stress-related degenerative effects [4-6].

Eucalyptus species from Myrtaceae family has been widely explored on their various pharmacological activities such as analgesic, antifungal, anti-inflammatory, antibacterial, antidiabetic, antioxidative, antiviral, antitumor, antihistaminic, anticancer, cytochrome p450 inhibitor, and hepatoprotective properties [7].

The previous studies on fruits from plants of Myrtaceae family showed that phenolic compounds, such as ellagic acid, rutin, and quercetin, contributed to antioxidant activity. They could be found in Eugenia brasiliensis, Melaleuca cauliflora, Melaleuca vexator, Syzygium curranii, Syzygium cumini, Syzygium malaccense, Syzygium samarangense Syzygium jambos, and Psidium guajava $[8,9]$.

Previous studies confirmed that seeds of Syzygium aromaticum have a number of polyphenols including ellagic acid $(9.08 \mathrm{mg} / \mathrm{kg})$, ellagic acid derivative $(3.46 \mathrm{mg} / \mathrm{kg})$, gallic acid $(28.55 \mathrm{mg} / \mathrm{kg})$, and quercetin glucoside $(3.53 \mathrm{mg} / \mathrm{kg}$ ) [10]. Eugenol of S. aromaticum has suppressive effects on arthritic rats [11].

Part of Syzygium aqueum (fruit) has been confirmed to have $4.1 \mathrm{mg} / 100 \mathrm{~g}$ of ascorbic acid content, $35.0 \mathrm{mg} / 100 \mathrm{~g}$ of total phenol content, and $31.0 \mathrm{mg} / 100 \mathrm{~g}$ of ascorbic acid equivalent antioxidant activity, meaning have mild antioxidant activity [12].

Until now, the information regarding antioxidant activity from the leaves of Myrtaceae was still limited. The aim of this study was to observe antioxidant activity from the leaves of Eucalyptus deglupta, S. mallaccenses, S. samarangense, P. guajava, S. cumini, S. aquaeum, S. aromaticum, Melaleuca leucadendra, and S. polyanthum.

\section{METHODS}

\section{Plants material}

The leaves of S. jambos, E. deglupta, S. mallaccenses, S. samarangense, and S. cumini were collected from Indonesian Institute of Sciences, Center for Plant Conservation - Bogor Botanical Gardens (Bogor, West Java, Indonesia) and the leaves of P. guajava, S. aqueum, S. aromaticum, M. leucadendra, and S. polyanthum were collected from various places in Bandung, West Java, Indonesia.

\section{Extraction}

The dried plant material was powdered using a grinder. It was weighed $(300 \mathrm{~g})$ and extracted with various solvents, which had gradual polarity such as hexane, ethyl acetate, and methanol using Soxhlet apparatus. The solvents were evaporated under reduced pressure using a rotary evaporator, and a greenish-black colored sticky residue would be obtained.

\section{2,2-diphenyl-1-picrylhydrazyl (DPPH) radical scavenging assay} The antioxidant activity of the plant's extracts and preparation of DPPH solution were adopted from Blois [13] by making some modifications. The diluted working solutions of the test extracts and DPPH were prepared in methanol. Each extract (various concentrations) was mixed 
with DPPH solution at a concentration rate of $50 \mu \mathrm{g} / \mathrm{ml} \mathrm{(1:1)} \mathrm{to} \mathrm{initiate}$ the reaction. After 30 minutes incubation, the absorbance was read at a wavelength 515-517 $\mathrm{nm}$ using spectrophotometer ultraviolet-visible. Methanol p.a. (1.5 ml) and DPPH solution (50 $\mu \mathrm{g} / \mathrm{ml}, 1.5 \mathrm{ml})(1: 1)$ were used as a blank. Based on the reduction of DPPH absorbance, the antioxidant activity of each extract was determined by calculating percentage of radical scavenging activity, as follow:

Radical scavenging activity $(\%)=\frac{\text { Ao-As }}{\text { Ao }} \times 100$

Where Ao is absorbance of DPPH in methanol and As is absorbance of DPPH in methanol plus sample solution (1:1). Inhibitory concentration $50 \%\left(\mathrm{IC}_{50}\right)$ was obtained by plotting the correlation of extract concentration and radical scavenging activity (\%). Ascorbic acid was used as the reference. Analysis was performed in triplicate for each extract and standard.

\section{RESULTS}

The DPPH radical scavenging activity is one of the most widely-used methods to screen the antioxidant activity on plant extracts. Table 1 shows the antioxidant activity of hexane, ethyl acetate, and methanolic extracts of 10 Myrtaceae plant leaves.

\section{DISCUSSION}

Methanol extracts produced moderate to high DPPH scavenging activity with values of $\mathrm{IC}_{50}$ were $7.90-26.03 \mu \mathrm{g} / \mathrm{ml}$. The highest DPPH scavenging activity was observed in $S$. jambos (7.90). In ethyl acetate extracts, the

Table 1: Results of antioxidant activity of plant extracts

\begin{tabular}{|c|c|c|}
\hline Plants (Leaves) & Solvents & $\mathrm{IC}_{50}(\mu \mathrm{g} / \mathrm{ml})$ \\
\hline \multirow[t]{3}{*}{ E. deglupta } & Methanol & $9.71 \pm 0.09$ \\
\hline & Ethyl acetate & $36.13 \pm 1.34$ \\
\hline & Hexane & $21356.24 \pm 10778.96$ \\
\hline \multirow[t]{3}{*}{ M. leucadendra } & Methanol & $22.46 \pm 0.69$ \\
\hline & Ethyl acetate & $69.04 \pm 1.64$ \\
\hline & Hexane & $289.53 \pm 3.70$ \\
\hline \multirow[t]{3}{*}{ P. guajava } & Methanol & $16.59 \pm 0.51$ \\
\hline & Ethyl acetate & $53.54 \pm 2.23$ \\
\hline & Hexane & $651.40 \pm 20.31$ \\
\hline \multirow[t]{3}{*}{ S. аquеuт } & Methanol & $20.24 \pm 0.65$ \\
\hline & Ethyl acetate & $65.12 \pm 0.60$ \\
\hline & Hexane & $515.48 \pm 16.70$ \\
\hline \multirow[t]{3}{*}{ S. aromaticum } & Methanol & $21.51 \pm 0.42$ \\
\hline & Ethyl acetate & $22.27 \pm 0.69$ \\
\hline & Hexane & $13.70 \pm 0.05$ \\
\hline \multirow[t]{2}{*}{ S. cumini } & Methanol & $16.91 \pm 0.37$ \\
\hline & Ethyl acetate & $48.06 \pm 4.89$ \\
\hline \multirow[t]{3}{*}{ S. jambos } & Hexane & $12.58 \pm 22.99$ \\
\hline & Methanol & $7.90 \pm 0.21$ \\
\hline & Ethyl acetate & $11.52 \pm 0.47$ \\
\hline \multirow[t]{3}{*}{ S. malaccences } & Hexane & $514.79 \pm 7.66$ \\
\hline & Methanol & $10.77 \pm 0.17$ \\
\hline & Ethyl acetate & $31.12 \pm 0.81$ \\
\hline \multirow[t]{3}{*}{ S. polyanthum } & Hexane & $3121.37 \pm 227.73$ \\
\hline & Methanol & $26.03 \pm 0.28$ \\
\hline & Ethyl acetate & $73.15 \pm 2.23$ \\
\hline \multirow[t]{2}{*}{ S. samarangense } & Hexane & $96.42 \pm 1.98$ \\
\hline & Methanol & $13.85 \pm 0.42$ \\
\hline \multirow[t]{3}{*}{ Ascorbic acid } & Ethyl acetate & $100.47 \pm 1.34$ \\
\hline & Hexane & $693.30 \pm 21.06$ \\
\hline & Methanol & $3.94 \pm 0.09$ \\
\hline
\end{tabular}

$\mathrm{IC}_{50}$ : Inhibitory concentration $50 \%$, E. deglupta: Eucalyptus deglupta, M. leucadendra: Melaleuca leucadendra, P. guajava: Psidium guajava, S. aqueum: Syzygium aqueum, S. aromaticum: Syzygium aromaticum, S. cumini: Syzygium cumini, S. jambos: Syzygium jambos,

S. malaccenses: Syzygium malaccense, S. polyanthum: Syzygium polyanthum,

S. samarangense: Syzygium samarangense highest scavenging activity was observed in $S$. jambos (11.52). While in hexane extract, the highest scavenging was observed in S. cumini (12.58).

The result showed that methanol extracts have higher antioxidants, compared to other solvents in DPPH assay. The antioxidant activity of observed methanol extract in $S$. jambos and E. deglupta was nearly the same, compared to ascorbic acid (3.94 $\mu \mathrm{g} / \mathrm{mL})$. The antioxidant activity with an IC $_{50}$ value of $<10 \mu \mathrm{g} / \mathrm{ml}$ could be considered as a good antioxidant and an $\mathrm{IC}_{50}$ value of $10-50 \mu \mathrm{g} / \mathrm{ml}$ could be considered as a powerful antioxidant [14].

A previous study by Reynertson et al. [8] exposed that methanolformic acid (9:1) fruit extract of $S$. cumini, S. jambos, S. malaccense, and $S$. samarangense has $\mathrm{IC}_{50}$ values of $389,92,269$, and $78 \mu \mathrm{g} / \mathrm{ml}$, respectively. Despite the fact that there are slight differences in the solvent and extraction method, it can be seen that leaves have higher antioxidant potential, compared to fruits.

The result on this study showed that extract of $S$. aqueum has $\mathrm{IC}_{50}$ values of $20.24 \mu \mathrm{g} / \mathrm{ml}$ for leaves and from a previous study has $\mathrm{IC}_{50}$ values of $12.00 \mu \mathrm{g} / \mathrm{ml}$ for fruits [12], confirming that fruits have higher antioxidant potential, compared to leaves.

A previous study by El-Ahmad et al., confirmed that guava leaf oil reduced DPPH radicals with an $\mathrm{IC}_{50}$ value of $3.59 \mu \mathrm{g} / \mathrm{ml}$ [15]. Supporting the result from that previous study, this study confirmed that leaves of P. guajava have potential antioxidant activity. In line with the previous studies [16-20], this study also indicated that leaves of $M$. leucadendra and $S$. polyanthum have mild potential antioxidant activity.

The essential oil of $S$. aromaticum (buds) was significantly found in antioxidants, such as superoxide dismutase, glutathione reductase, and glutathione S-transferase [21]. This confirmed that S. aromaticum has an antioxidant activity, both in leaves and buds.

However, the chemical constituents that were responsible for this activity would require further investigation, since the observed antioxidant activity might be due to the presence of several constituents.

\section{CONCLUSIONS}

It can be concluded that methanol extracts have better antioxidant activities, compared to other solvents. The $\mathrm{IC}_{50}$ values of methanol extracts were varied between 7.90 and $26.03 \mu \mathrm{g} / \mathrm{ml}$, while $\mathrm{IC}_{50}$ values of ascorbic acid were $3.94 \mu \mathrm{g} / \mathrm{ml}$. The methanol extract of $S$. jambos showed the highest antioxidant activity among all extracts with an $\mathrm{IC}_{50}$ value of $7.90 \mu \mathrm{g} / \mathrm{ml}$

\section{ACKNOWLEDGMENT}

This research was funded by Riset Inovasi KK ITB.

\section{REFERENCES}

1. Sies H. Oxidative stress: Oxidants and antioxidants. Exp Physiol 1997;82(2):291-5.

2. Mark P. Antioxidant. Clin Nutr Insights 1998;31:1-4

3. Sies H, Stahl W, Sundquist AR. Antioxidant function of vitamins. Ann NY Acad Sci 1992;669:7-20.

4. Sen T, Nasralla HS, Chaudhuri AK. Studies on the anti-inflammatory and related pharmacological activities of Psidium guajava: A preliminary report. Phytother Res 1995;9 Suppl 2:118-22.

5. Surh YJ. NF-kappa B and Nrf2 as potential chemopreventive targets of some anti-inflammatory and antioxidative phytonutrients with anti-inflammatory and antioxidative activities. Asia Pac J Clin Nutr 2008;17 Suppl 1:269-72.

6. Youdim KA, Joseph JA. A possible emerging role of phytochemicals in improving age-related neurological dysfunctions: A multiplicity of effects. Free Radic Biol Med 2001;30(6):583-94.

7. Kumar HD, Laxmidhar S. A review on phytochemical and pharmacological of Eucalyptus globulus: A multipurpose tree. Int J Res Ayurveda Pharm 2011;2 Suppl 5:1527-30. 
8. Reynertson KA, Yang H, Jiang B, Basile MJ, Kennelly EJ. Quantitative analysis of antiradical phenolic constituent from fourteen edible Myrtaceae Fruits. Food Chem 2008;109:883-90.

9. Rosa MP, Sylvia M, Rosario VS. Psidium guajava: A review of its traditional uses, phytochemistry and pharmacology. J Ethnopharmacol 2008;117:1-27.

10. Atawodi SE, Atawodi JC, Pfundstein B, Spiegelhalder B, Bartsch H, Owen R. Assessment of the polyphenol components and in vitro antioxidant properties of Syzygium aromaticum (L.) Merr. And Perry. Electron J Environ Agric Food Chem 2011;10 Suppl 3:1970-8.

11. Sharma JN, Srivastava KC, Gan EK. Suppressive effects of eugenol and ginger oil on arthritic rats. Pharmacology 1994;49(5):314-8.

12. Lim YY, Lim TT, Tee JJ. Antioxidant properties of several tropical fruits: A comparative study. Food Chem 2007;103:1003-8

13. Blois MS. Antioxidant determination by the use of a stable free radical. Nature 1958;181:1199-200.

14. Phongpaichit S, Nikom J, Rungjindamai N, Sakayaroj J, Hutadilok-Towatana N, Rukachaisirikul V, et al. Biological activities of extracts from endophytic fungi isolated from Garcinia plants. FEMS Immunol Med Microbiol 2007;51(3):517-25.

15. El-Ahmady SH, Ashour ML, Wink M. Chemical composition and anti-inflammatory activity of the essential oils of Psidium guajava fruits and leave. J Essent Oil Res 2013;25(6):1-7.

16. Darusman LK, Wahyuni WT, Alwi F. Acetylcholinesterase inhibition and antioxidant activity of Syzygium cumini, S. Aromaticum and S. polyanthum from Indonesia. Pak J Biol Sci 2013;13 Suppl 5:412-6.

17. Surh J, Yun JM. Antioxidant and anti-inflammatory activities of butanol extract of Melaleuca leucadendron L. Prev Nutr Food Sci 2012;17(1):22-8.

18. Lee WH, Intan SI. Antioxidant activity, total phenolics and total flavonoids of Syzygium polyanthum (Wight) walp leaves. Int J Med Aromat Plants 2012;2:219-28.

19. Kusuma IW, Kuspradini H, Arung ET, Min YH, Kim YU. Biological activity and phytochemical analysis of three Indonesian medicinal plants, Murraya koenigii, Syzygium polyanthum and Zingiber purpurea. J Acupunct Meridian Stud 2011;4 Suppl 1:75-9.

20. Pujiarti R, Yoshito O, Hideaki I. Antioxidant, anti-hyaluronidase and antifungal activities of Melaleuca leucadendron Linn. Leaf oils. J Wood Sci 2012;58 Suppl 5:429-36.

21. Amrita S, Praveen D. Phytochemical analysis, antioxidant and antimicrobial activity of Syzgium caryophyllatum essential oil. Asian J Pharm Clin Res 2014;7 Suppl 2:202-5. 